\title{
Planting depth and soil texture effects on emergence and production of three alkali sacaton accessions
}

\author{
ABRAHAM DE ALBA-A VILA AND JERRY R. COX
}

\begin{abstract}
Pure stands of alkali sacaton (Sporobolus airoides) once grew on playas and lowland alluvial flood plains, as well as on surrounding hills and terraces in semiarid areas of North America. Stands have all but disappeared on hills and terraces in the past 100 years. The purpose of this research was to evaluate the establishment and initial production characteristics of 3 alkali sacaton accessions when seeds were sown at various depths in 3 soils where soluble salts and exchangeable sodium do not accumulate. 'Saltalk', 'NM184 ' and 'DU-82' accessions were sown at 5 depths in Pima finesilty, Sonoita coarse-loam, and Comoro coarse-loam soils in a greenhouse. Seedling emergence from seed sown at $5 \mathrm{~mm}$ was greater than for seed sown at 0, 10, 15, and $20 \mathrm{~mm}$ in Comoro (sandy), but was equal at all depths in the cracking Pima soil. Above- and below-ground biomass were greatest in Comoro, intermediate in Pima, and lowest in Sonoita soils, but differences were not always significant. The 3 accessions responded similarly to planting depth within a soil, although initial emergence counts indicate differences among accessions.
\end{abstract}

Key Worda: Sporobolus airoides, solls, planting depths, emergence, growth and production, Chihuahuan and Sonoran Deserts

Alkali sacaton (Sporobolus airoides), a perennial warm-season bunchgrass is distributed from North Dakota to eastern Washington (USA) and from Zacatecas to southern Sinaloa (Mexico) in North America (Gould 1975, Hitchcock 1950). One hundred years ago, this grass could be found growing in soils on playas and flood plains, and in soils on hills and terraces. Today the species is found growing only in soils on playas and low alluvial flood planes where water and excessive concentrations of either soluble salts or exchangeable sodium, or both, accumulate (Hickey and Springfield 1966, Knipe and Springfield 1972).

Because alkali sacaton persisted only where water and either soluble salts or exchangeable sodium accumulated, it has been assumed that the species is adapted only to these soil environments (McFarland et al. 1987, School and Miyamoto 1984). Therefore, attempts to reestablish this grass from seed have been limited to mesic, salty soils (Cox et al. 1982).

The seed of 25 alkali sacaton accessions were sown in 3 soils where soluble salts and exchangeable sodium concentrations were either high or low, and we measured seedling emergence and forage production (unpublished data, USDA-ARS and USDA-SCS, Tucson, Ariz.). The seedling emergence and forage production of 23 accessions averaged $10 \%$ and $25 \mathrm{~g} /$ plant, respectively, and neither measure changed as salt or sodium concentrations varied. For 2 accessions, 'Saltalk' and 'NM-184', emergence increased from 15 to $30 \%$ and forage production from 55 to $85 \mathrm{~g} /$ plant as salt and sodium concentrations decreased. 'Saltalk' emergence appeared to increase when seed were sown in fine textured soils, while 'NM'-184' emergence appeared to increase when seed were sown in loam textured soils.

\footnotetext{
Authors are ecologist and former graduate student, Instituto Nacional de Agricolas del Norte Centrol (CEDEC), Apartado 69, Jalpo, ZAC., 99690, Mexico; and range scientist USDA-Agricultural Research Service, 2000 E. Allen Road, Tucson, Arizona 85719. Reprint requests should be sent to J.R. Cox.

Financial support for this research was provided by a U.S. Agency for International Development fellowship to the senior author, facilities were provided by Aridland Watershed Management and Biological Control of Insects Research Units, USDAAgriultural Research Service, Tucson, Arizona.

Manuscript accepted 15 December 1987.
}

'Saltalk' and 'NM-184' were selected because they were easy to establish (unpublished data, USDA-SCS, Beltsville, Maryland). Both have been widely seeded in the western United States on fine textured soils where salts and sodium accumulate, but neither is widely used because seedlings are difficult to establish (Cox et al. 1982). This study was initiated to determine the emergence and forage production potential of 'Saltalk' and 'NM-184'. Both accessions are commercially unavailable in Mexico. Therefore, seed collected at Mapimi Biosphere Reserve, Durango, Mexico ('DU82) was included for comparative purposes. To determine soil textural affects on seedling emergence and forage production, we collected soils at 3 sites where soluble salts and exchangeable sodium had not accumulated in high concentrations.

\section{Methods and Materials}

In preliminary laboratory studies we found that seed germination among the 3 alkali sacaton accessions varied from 5 to $20 \%$, and variability was great among replicates of the same accession. Seed lots were separated on $26,28,30,32,34,36$, and $38 \mathrm{~mm}$ screens, and seed of each size class were germinated on moist filter paper in plastic petri dishes at $30^{\circ} \mathrm{C}$. Mean germination of seed collected from the 32-mm screen varied from 30 to $35 \%$ among the 3 accessions, and the variability among replicates was less than $10 \%$ of the mean.

Soils with textural characteristics common to the desert regions of the southwestern United States and northern Mexico, where alkali sacaton grasslands once occurred, were collected at $\mathbf{0}$ to 30 $\mathrm{cm}$ depths in the summer of 1984 . Comoro soil (Table 1) was

Table 1. Textural characteristics and clasdification of 3 solls commonly found in the Chihuahuan and Sonoran Deserts of North America.

\begin{tabular}{|c|c|c|c|c|}
\hline \multirow{2}{*}{$\begin{array}{l}\text { Soil } \\
\text { Series }\end{array}$} & \multicolumn{3}{|c|}{ Texture } & \multirow[b]{2}{*}{ Soil family classification ${ }^{1}$} \\
\hline & Sand & Silt & Clay & \\
\hline & & $\%$ & & \\
\hline Comoro & 65 & 25 & 10 & $\begin{array}{l}\text { Coarse-loamy, mixed thermic } \\
\text { Typic Torrifluvent }\end{array}$ \\
\hline Sonoita & 50 & 25 & 25 & $\begin{array}{l}\text { Coarse-loamy, mixed, thermic } \\
\text { Typic Haplargid }\end{array}$ \\
\hline Pima & 30 & 30 & 40 & $\begin{array}{l}\text { Fine-silty, mixed } \\
\text { (calcareous), thermic Typic } \\
\text { Torrifluvent }\end{array}$ \\
\hline
\end{tabular}

${ }^{1}$ Classification follows Soil Survey Staff 1975.

collected in the foothills near the Santa Rita Mountains, Sonoita soil on a secondary terrace above the Santa Cruz river, and Pima soil on a primary terrace within the Santa Cruz flood plain. Soluble salts and exchangeable sodium do not accumulate in high concentrations in these soils (Richardson et al. 1979). The clay fraction in both the Comoro and Sonoita soils is predominantly kaolinite, while in Pima the dominant fraction is montmorillionite (Gelderman 1972).

Soils were screened to $1 \mathrm{~cm}$ to remove rocks, and added to $203 \mathrm{cc}$ tapered plastic plots at $130,125,120,115$, and $110 \mathrm{~mm}$ depths above the pot base. To obtain 25 germinable alkali sacaton seed, either 83 ('DU-82') or 71 ('Saltalk'and 'NM-184) seeds from each 
Table 2. Probability levels $(*=0.05, * *=0.01, * * *=0.001$, NS=non-significant) of orthogonal polynomials used to evaluate differences among 3 alkali sacaton accessions; when seed were sown at 5 depths in 3 soils.

\begin{tabular}{|c|c|c|c|c|c|c|c|c|}
\hline & \multicolumn{6}{|c|}{ Days after planting } & \multirow{3}{*}{$\begin{array}{l}\text { Above- } \\
\text { ground } \\
\text { biomass }\end{array}$} & \multirow{3}{*}{$\begin{array}{l}\text { Below- } \\
\text { ground } \\
\text { biomass }\end{array}$} \\
\hline & \multicolumn{3}{|c|}{ Emergence } & \multicolumn{3}{|c|}{ Shoot lengths } & & \\
\hline & 10 & 20 & 30 & 10 & 20 & 30 & & \\
\hline \multirow{3}{*}{$\begin{array}{l}\text { Accession (A) } \\
\text { Soil (S) }\end{array}$} & \multicolumn{3}{|c|}{$-\%-$} & \multicolumn{3}{|c|}{$-m m-$} & \multicolumn{2}{|c|}{$-g /$ pot- } \\
\hline & NS & $\bullet * *$ & $* * *$ & *** & $* * *$ & $* * *$ & NS & NS \\
\hline & $* * *$ & $* * *$ & $* * *$ & $* * *$ & $* * *$ & $* * *$ & $\omega *$ & $* * *$ \\
\hline Depth (D) & $* * *$ & $* * *$ & $* * *$ & $* * *$ & $* * *$ & $* *$ & ** & $* *$ \\
\hline Linear & $* * *$ & $* * *$ & NS & $* * *$ & $* * *$ & $* * *$ & $* * *$ & $*$ \\
\hline Quadratic & NS & $* * *$ & *** & NS & NS & NS & NS & $* * *$ \\
\hline$A \times S$ & NS & ** & $* *$ & NS & NS & NS & NS & NS \\
\hline $\mathbf{A} \times \mathbf{D}$ & $* * *$ & $* * *$ & $* * *$ & NS & NS & NS & NS & NS \\
\hline Linear & $* * *$ & $* * *$ & $* * *$ & NS & NS & NS & NS & NS \\
\hline Quadratic & $* *$ & ** & $*$ & NS & NS & NS & NS & NS \\
\hline $\mathbf{S} \times \mathbf{D}$ & $\omega * *$ & $* * *$ & $* * *$ & $* * *$ & $*$ & $*$ & $* *$ & 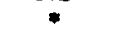 \\
\hline Linear & NS & $* * *$ & $* * *$ & $* * *$ & $*$ & ** & $*$ & $*$ \\
\hline Quadratic & $* * *$ & $* *$ & $* *$ & NS & NS & NS & NS & $*$ \\
\hline $\mathbf{A} \times \mathbf{S} \times \mathbf{D}$ & NS & NS & NS & NS & NS & NS & NS & NS \\
\hline
\end{tabular}

accession were sown on the soil surface in separate pots. Soils were added to $130 \mathrm{~mm}$ depths in all pots; thus, seeds were planted at 0,5 , 10,15 , and $20 \mathrm{~mm}$ depths. Pots were subirrigated with distilled water continuously for 7 days, and thereafter for $8 \mathrm{~h}$ on days 10,15 , 20 , and 25 . Sub-irrigation was used to minimize soil disturbance and seed movement.

Greenhouse relative humidity varied from 58 to $80 \%$, and temperatures ranged from 27 to $32^{\circ} \mathrm{C}$. Day length was $10.5 \mathrm{~h}$, and no supplemental light or fertilizer was added.

Seedling emergence was considered complete when the first leaf was $15 \mathrm{~mm}$ above the soil surface and the seedling radicle had penetrated the soil surface in pots where seed were surface sown. Shoot lengths, the distance from the soil surface to the extended leaf tips, of the 3 tallest plants in each pot and emergence were measured 10, 20, and 30 days after the experiment began. After seedlings were counted and leaves were measured on the 30th day, shoots were harvested at the soil surface, and roots were washed from soil. Plant material was dried at $40^{\circ} \mathrm{C}$ for $48 \mathrm{~h}$ in a forceddraft oven and weighed.

Pots were arranged in a randomized complete block design, with a $3 \times 3 \times 5$ factorial arrangement. There were 6 blocks and each contained 3 soils, 3 accessions, and 5 planting depths. Data were arcsin transformed and subjected, by date, to analyses of variance (ANOVA). ANOVA included orthogonal and polynomial decomposition of depth effects into linear and quadratic components and the identification of significant main effects and interactions (Table 2). Cubic and quartic components were not included because depth degrees of freedom (4) were limited. When the accession by soil interaction was significant $(P \leq 0.05)$, means were separated by Tukey's HSD test (Sokal and Rohlf 1981).

\section{Results}

Seed of the 3 alkali sacaton accessions sown on the 3 soil surfaces began to germinate on day 5 and ranged from 75 to $95 \%$ on day 10 . 'Saltalk' and 'NM-184' seedlings grew more rapidly than 'DU-82', and $60 \%$ or more of their viable seeds had produced seedlings which exceeded $15 \mathrm{~mm}$ on day 10 (Fig. 1A). 'DU-82' densities were as numerous and appeared to be as healthy as 'Saltalk' and 'NM$184^{\prime}$, but seedlings were smaller.

Seminal roots of seed sown on Comoro soil quickly penetrated the soil surface, but approximately $50 \%$ of the roots from seed of each accession grew horizontally along the Sonoita and Pima soil surfaces for 24 to $36 \mathrm{~h}$. Seminal roots of most seedlings penetrated the Sonoita and Pima soils within 24 to $36 \mathrm{~h}$, but leaves were elevated and a portion of the root exposed to air. Seedlings not penetrating the soil surfaces died after 7 days when sub-irrigation was discontinued and soil surfaces dried. Seedling emergence declined with planting depth in Sonoita and Pima soils on day 10, but increased when seed were sown at 5 and $10 \mathrm{~mm}$ depths in Comoro soil (Fig. 2A).

'DU-82' seedlings from surface-sown seed with exposed seminal roots died as surface soils dried between sub-irrigations on days 10 and 15 . 'DU-82' emergence increased by $10 \%$ between 10 and 20 days, while 'Saltalk' and 'NM-84' emergence increased $40 \%$ (Fig. 1B). Accession emergence from $5 \mathrm{~mm}$ planting depths either equalled or exceeded emergence from surface sown seed by day 20 , and declined with depth.

As soils dried following sub-irrigation, cracks $30 \mathrm{~mm}$ deep appeared in the Pima soils. Seedlings emerged from these cracks between 10 and 15 days (Fig. 2B). Seedlings from seed sown in the non-expanding Sonoita soil emerged more slowly.

The pure live seed estimates, based on standard laboratory testing techniques, did not correspond with seedling emergence once seed had been placed in soil. Hence, estimates from laboratory techniques may underestimate germination when seed are planted in soil. 'Saltalk' emergence from 0-15 mm, 'NM-184' from 0-10 mm and 'DU-82' from $10 \mathrm{~mm}$ depths exceeded $100 \%$ of the pure live seed on day 30 (Fig. 1C) and the majority of the seedlings emerged from 5 and $10 \mathrm{~mm}$ depths in the 3 soils (Fig. 2C). 'Saltalk' emergence by day 30 was $12 \%$ more than the mean emergence of 'NM-184' and 'DU-82' on Comoro soil, and 'Saltalk' and 'NM-184' were superior to 'DU-82' on Sonoita and Pima soils (Table 3).

Seedling shoot length, in this instance used as a measure of plant vigor, was greatest for seedlings developing from surface sown seed and declined with planting depth at days 10 and 20 (Fig. 3A and B).

Table 3. Emergence of 3 alkali sacaton accessions from 3 soils 20 and 30 days after planting seed.

\begin{tabular}{llllr}
\hline \hline \multirow{2}{*}{$\begin{array}{l}\text { Days after } \\
\text { plantingl }\end{array}$} & Accessions & \multicolumn{3}{c}{ Soils } \\
\cline { 3 - 5 } 20 & Saltalk & Comoro & Sonoita & Pima \\
\hline \multirow{2}{*}{30} & NM-184 & $96 \mathrm{a}$ & $79 \mathrm{~b}$ & $101 \mathrm{a}$ \\
& DU-82 & $87 \mathrm{~b}$ & $95 \mathrm{a}$ & $96 \mathrm{a}$ \\
& Saltalk & $83 \mathrm{~b}$ & $71 \mathrm{~b}$ & $79 \mathrm{~b}$ \\
& NM-184 & $97 \mathrm{a}$ & $116 \mathrm{a}$ & $119 \mathrm{a}$ \\
& DU-82 & $87 \mathrm{~b}$ & $116 \mathrm{a}$ & $112 \mathrm{a}$ \\
& & $84 \mathrm{~b}$ & $93 \mathrm{~b}$ & $80 \mathrm{~b}$ \\
\hline
\end{tabular}

'Means within dates and soils followed by the same letters are not significantly different $(P \leq 0.05)$. 
(A)

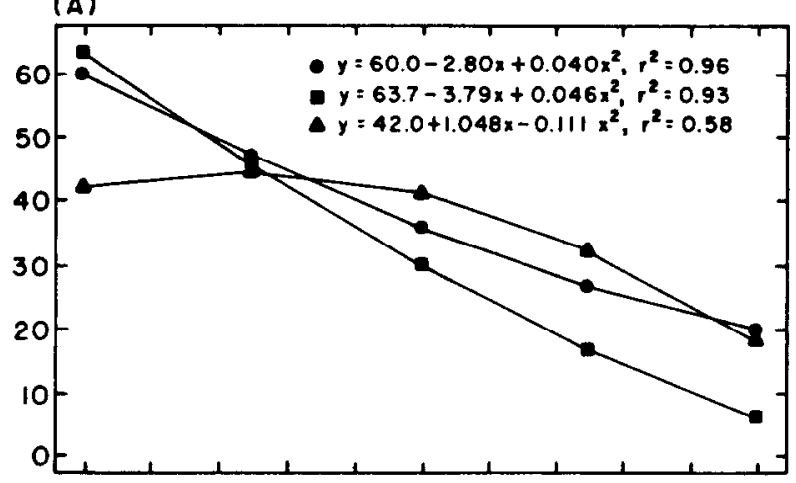

(B)

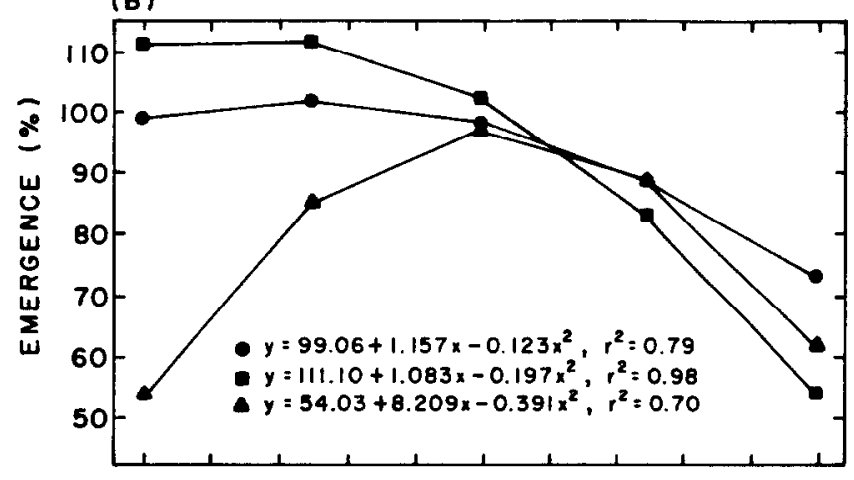

(c)

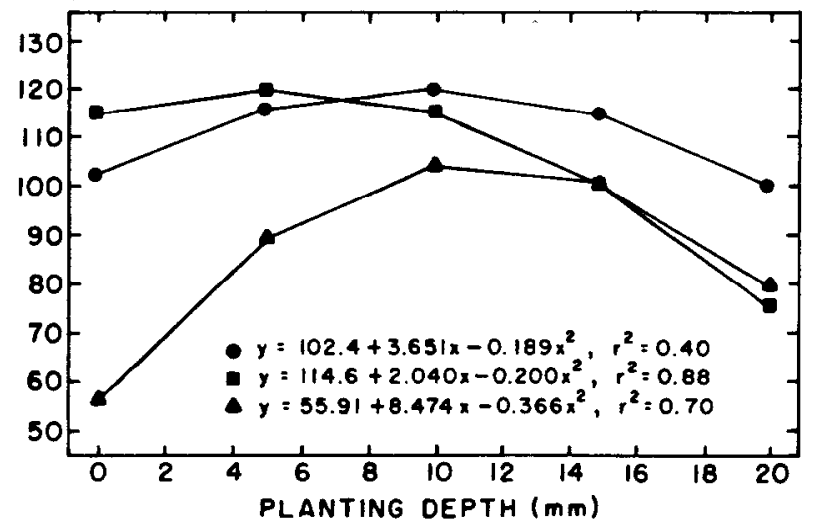

Fig. 1. Predicted emergence of Sallalk ( $), N M-184$ (ם) and DU-82 (A) alkali sacaton accessions from seed sown at 5 depths 10 (A), 20 (B), and 30 (C) days after planting in 3 soils.

Differences among accessions did not occur, but seedlings in Comoro soil grew faster than seedlings in Sonoita and Pima soils. At the conclusions of the study (day 30, Fig. 3C) shoot lengths varied from 34 to $36 \mathrm{~cm}$ in Comoro and from 28 to $30 \mathrm{~cm}$ in Pima soil, and were unchanged among the 5 planting depths. In Sonoita soil, however, shoot lengths varied from 12 to $23 \mathrm{~cm}$ and declined with depth.

The amounts of above-ground biomass that accumulated were similar for the 3 accessions at 30 days (Table 2) but differed among soils and planting depths (Fig. 4A). Above-ground biomass was greatest when seedlings grew in Comoro soil, intermediate in Pima soil, and lowest in Sonoita soil. Above-ground biomass declined with planting depth in Comoro and Sonoita soils and was not influenced by planting depth in the cracking Pima soil.

Below-ground biomass was greatest in Comoro, intermediate in Pima, and least in Sonoita soil (Fig. 4B). Root biomass was higher
(A)
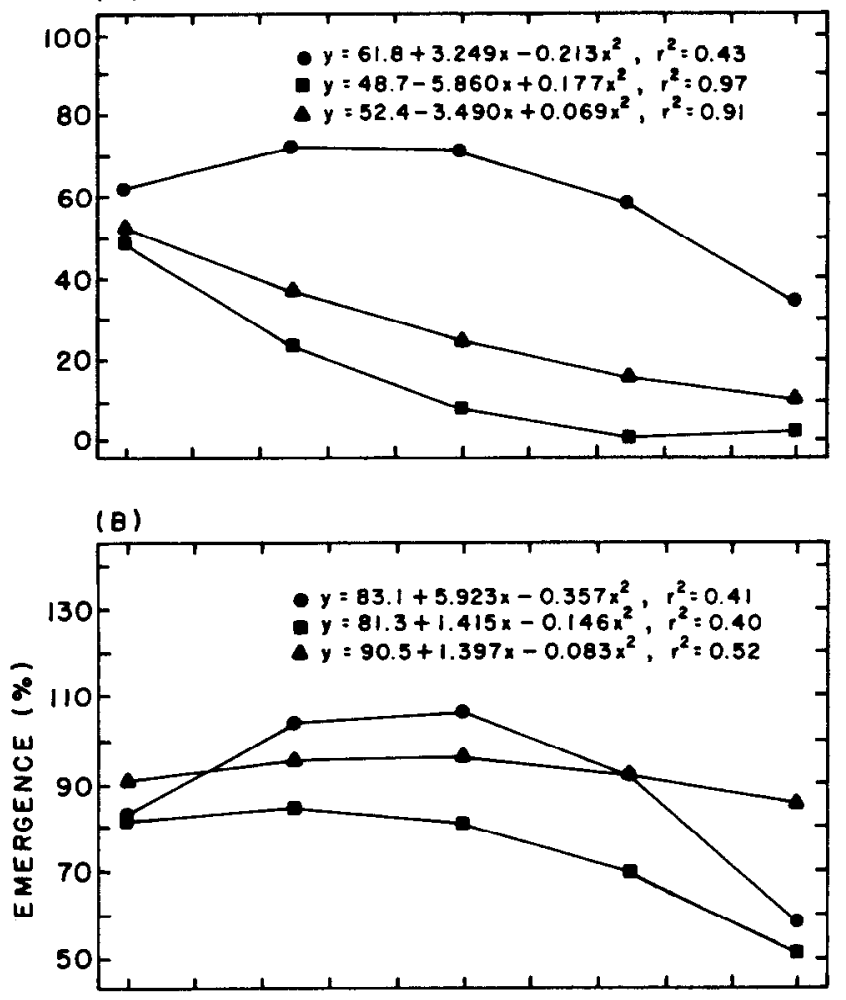

(c)

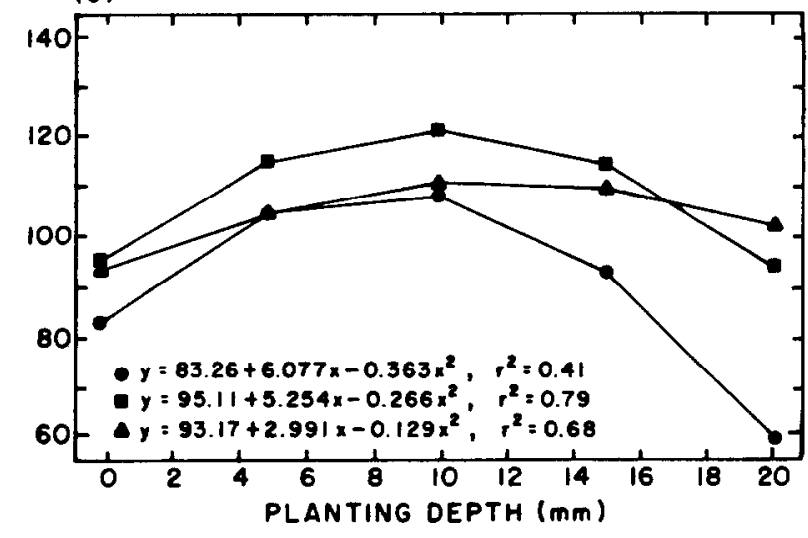

Fiz. 2. Predicted emergence of 3 alkali sacaton accessions from seed sown at 5 depths in Comoro ( $\bullet$ ), Sonoita (C), and Pima $\Delta$ ) soils 10 (A), 20 (B), and $30(C)$ days after planting.

when seed had been sown at $5 \mathrm{~mm}$ in the 3 soils, but differences among depths were not always significant.

Emergence differed among accessions, soils and depths but plant production was similar among accessions and differed among soils and planting depths. Accession emergence, shoot length, and production were greatest when seeds were sown in a coarse-textured soil where percent sand equalled 65 (Table 1), and in a finetextured soil that cracked as the surface dried. Plant emergence, vigor, and production declined when seed were sown in a coarse soil, where fine particles (clay plus silt) equalled $50 \%$ and the soil did not crack upon drying.

Accession shoot growth and above-ground production were either unaffected or declined by day 30 as planting depth increased in the 3 soils (Fig. 3C and Fig. 4A). However, emergence and root biomass by day 30 peaked when seed were sown at 5 and $10 \mathrm{~mm}$ depths and declined when seed were sown above or below. 
(A)

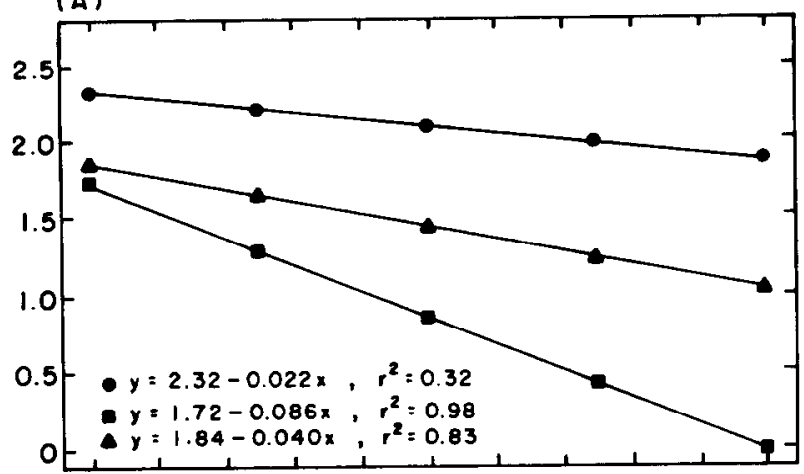

(B)

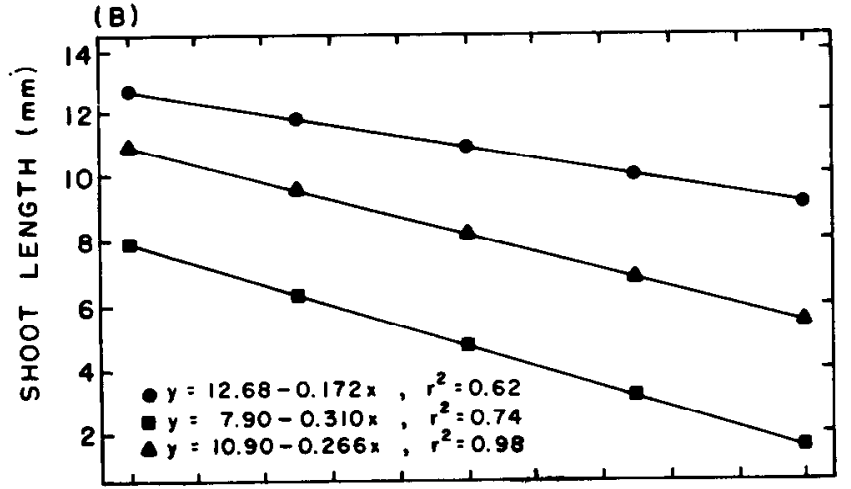

(c)

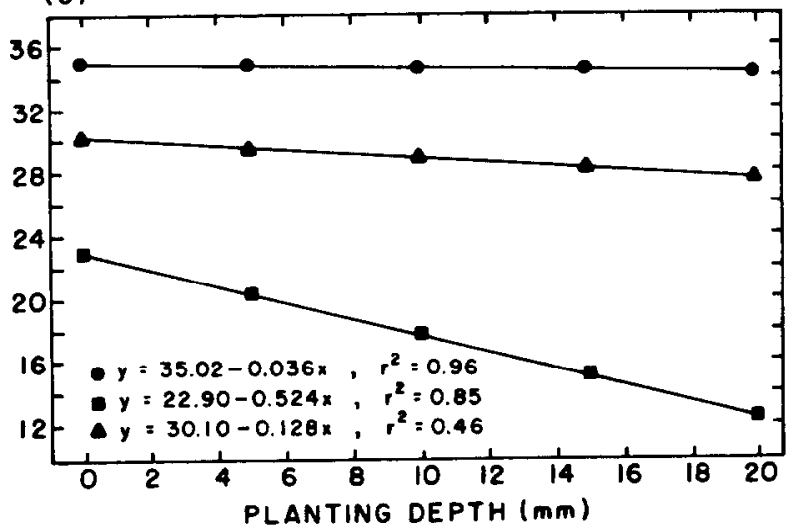

Fig. 3. Predicted shoot lengths of 3 alkali sacaton accessions from seed sown at 5 depths in Comoro ( $\bullet$ ), Sonoita (D), and Pima (A) soils 10 (A), $20(B)$, and 30 (C) days after planting.

\section{Discussion}

In the western United States and northern Mexico, living alkali sacaton plants are found where water accumulates in alluvial flood plains or in alkaline playas. Observations by the authors at more than 40 sites in the southwestern United States and Mexico tend to support the prevailing opinion that the species is only adapted to land areas were water accumulates, and where soils remain moist for extended periods. Logically, we might conclude that reseeding efforts should be confined to lowland areas where water accumulates.

Scattered alkali sacaton plants as well as dead crowns have been observed on hillsides and secondary terraces above flood plains (Hickey and Springfield 1966, Valentine and Norris 1964). These observations and the superior growth of the accessions in Comoro soil (Figs. 2, 3, and 4) support Dortignac's (1960) hypothesis that at one time the species grew throughout the Chihuahuan and Sonoran Deserts, regardless of soil texture.
(A)
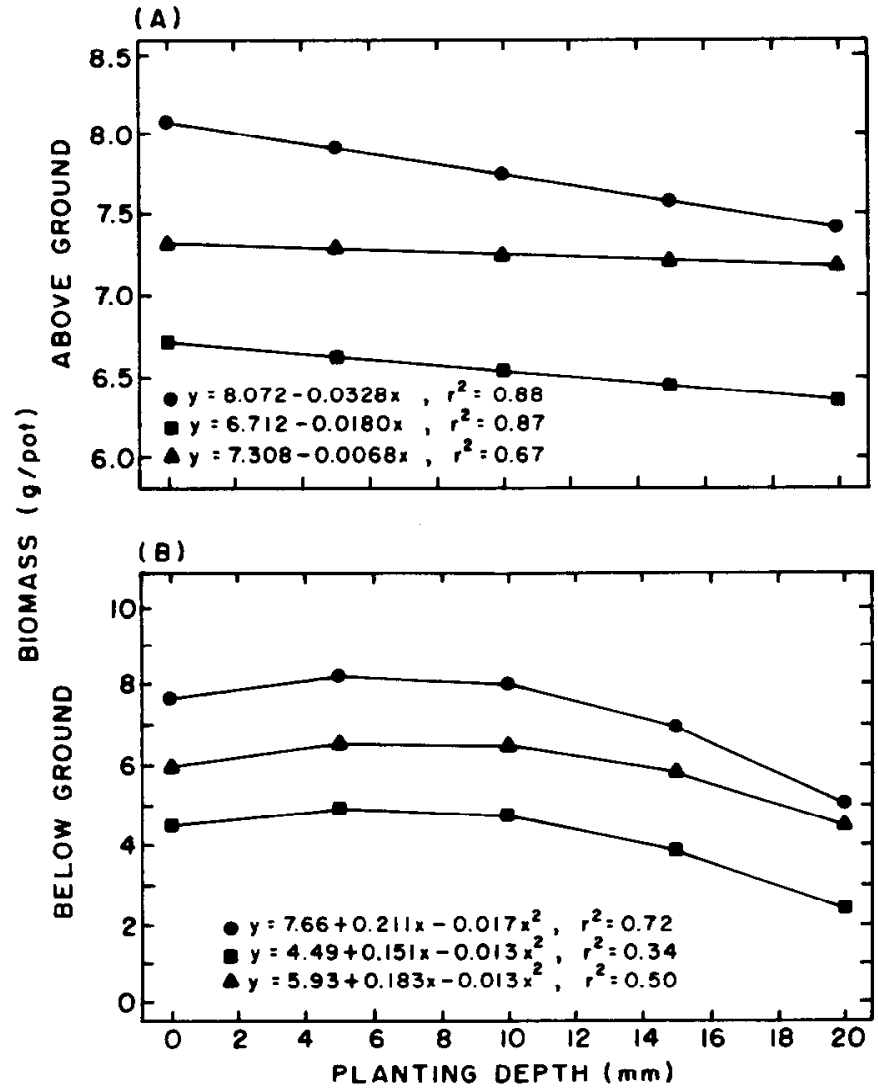

Fig. 4. Predicted accumulations of above- (A) and below (B) ground biomass of 3 alkali sacaton accessions from seed sown at 5 depths in Comoro ( () , Sonoita ( $)$, and Pima ( $\Delta$ ) soils 30 days after planting.

Because of overgrazing (Humphrey 1958) and possibly competition from other grasses and shrubs better adapted to non-saline and non-alkaline conditions (Hubbell and Gardner 1950), alkali sacaton currently survives only under ideal conditions, found in alluvial lowlands where runoff accumulates and soils crack. Heavily grazed plants may only be able to produce sufficient seed to maintain existing standings under ideal growing conditions (Knipe and Springfield 1972, Hickey and Springfield 1966). On hillsides and secondary terraces, where loam surface soils are commonly found (Richardson et al. 1979), stands may have died due to either insufficient seed or heavy grazing. Because alkali sacaton stands presently persist on fine textured soils where water and often exchangeable sodium and soluable salts accumulate, revegetation specialists have assumed that the species is adapted only to such sites (Scholl and Miyamoto 1984, McFarland et al. 1987). This study does not support that assumption.

\section{Literature Cited}

Cox, J.R., H.L. Morton, T.N. Johnsen, Jr., G.L. Jordan, S.C. Martin, and L.C. Flerro. 1982. Vegetation restoration in the Chihuahuan and Sonoran Deserts of North America. USDA-ARS Rep. ARM-W-28, Oakland.

Dortignac, E.J. 1960. The Rio Puerco-Past, present, and future. N.M. Water Conf. Proc. 5:45-51.

Gelderman, F.W. 1972. Soil survey of Tucson-Avra Valley area, Arizona. USDA-Soil Conserv. Serv, and Univ. Arizona Agr. Exp. Sta.

Gould, F.W. 1975. The grasses of Texas. Texas A\&M Univ. Press, College Sta.

Hickey, W.C., and H.W. Sprinffield. 1966. Alkali sacaton: Its mirits for forage and cover. J. Range Manage. 19:71-74.

Hitcheock, A.S. 1950. Manual of the grasses of the United States. USDA Misc. Pub. 200. U.S. Government Printing Office, Washington, DC.

Hubbell, D.S., and J.L. Gardner. 1950. Effects of diverting sediment-laden runoff from arroyos to range and crop lands. USDA Agr. Tech. Bull. 1012. 
Humphrey, R.R. 1958. The desert grassland; A history of vegetational changes and an analysis of causes. Botanical Review 24:193-252.

Knipe, O.D., and H.W. Springfield. 1972. Germinable alkali sacaton seed contents of soils in the Rio Puerco Basin, West Central New Mexico. Ecology 53:965-968.

McFarland, M.L., D.N. Ueckert, and S. Hartman. 1987. Revegetation of oil well reserve pits in West Texas. J. Range Manage. 40:122-127.

Richardson, M.L., G.D. Clemmons, and J.C. Walker. 1979. Soil survey of Santa Cruz and parts of Cochise and Pima Counties, Arizona. USDASoil Conserv. Serv. and Univ. Arizona Agr. Exp. Sta.
Scholl, D.G., and S. Miyamoto. 1984. Response of alkali sacaton and fourwing saltbush to various amendments on coal mine spoils from northeastern New Mexico. II. Sodic spoil. Reclamation and Revegetation Res. 2:243-252.

Soil Survey Staff. 1975. Soil taxonomy: A basic system of soil classification for making and interpreting soil surveys. USDA-SCS Agr. Handbook 436 U.S. Government Printing Office, Washington, DC.

Sokal, R.R., and F.J. Rohlf. 1981. Biometry. Freeman and Co., San Francisco.

Valentine, K.A., and J.J. Norris. 1964. A comparative study of soils of selected creosotebush sites in southern New Mexico. J. Range Manage. 17:23-32. 